UDC 339.187:608.1

DOI: https://doi.org/10.32782/2413-9971/2020-34-2

\author{
Aliyeva Aygun \\ Ph.D in Economics, \\ Head of Department "Public Relation» \\ of Institute of Control Systems of ANAS \\ Republic of Azerbaijan
}

\title{
THE MAIN PROMISING DIRECTIONS OF MODERN INNOVATIVE ECONOMIC DEVELOPMENT IN THE REPUBLIC OF AZERBAIJAN
}

\begin{abstract}
Summary. The main purpose of the study is to examine the current state of the organization of innovation activities in the national economy under the context of market relations. In recent years, an increase rates of economic development of the national economy has been observed in Azerbaijan. In international rating reports, Azerbaijan annually increases its economic position. The article also analyzes Azerbaijan's position in the field of innovation in international rating reports compared to other countries. The study shows that in recent years, the volume of innovative products produced in the economic sphere in Azerbaijan, the costs of technological innovations are low. At the same time, the Global Competitiveness Report shows that Azerbaijan's innovation capabilities are lower than of the other countries. The article analyzes the existing problems in the application of modern innovations in the economic sphere, presents suggestions and recommendations to eliminate them.
\end{abstract}

Key words: innovation, economic integration, national economy, macroeconomics, state policy, integration, investment.

Introduction and the problem statement. In recent years, economic measures have been taken in the Republic of Azerbaijan in the field of application of modern innovations in national economic spheres. It should be noted that all these processes have allowed our country to constantly expand cooperation with various international financial institutions in the direction of integration into the world economy. It should be noted that the realization of the national economic interests of Azerbaijan is based on the sustainable development of the national economy. In recent years, during the political and financial crises in all countries of the world, sustainable development has been observed in Azerbaijan.

Azerbaijan is constantly taking measures to diversify the national economy, increase efficiency, improve product quality and competitiveness, modernize all spheres of society, improve the living standards of the population and reach the level of developed countries in all these areas. Azerbaijan's economic achievements are highly valued by influential international organizations. At present, the socio-economic development strategy set in our country is being successfully implemented.

The creation of favorable conditions for the development of technological innovations in the economic sphere, along with the modernization of the technological base of the economy of Azerbaijan, can also increase the competitiveness and export orientation of products of national economic sectors. The above makes it necessary to develop a state innovation policy and a mechanism for its implementation, as well as the creation of a national innovation system. In the Republic of Azerbaijan, the innovative activity of enterprises belonging only to the non-oil sector will give impuls to increase their competitiveness $[1, \mathrm{p} .440]$.

Analysis of recent research and publication. Well-known scientific experts Shiray V.I. [4], Kolesov V.P. [3], Abdullayev K.N. [6], Shakaraliyev A.S. [1] noted the importance of increasing the role of state and private entrepreneurs in the expansion of innovations in the country. In other words, the result obtained from the reintegration of innovation is determined by its efficiency.

As it seems, the efficiency of innovation is determined by the ability to save labor, time, resources and money in the necessary and intended amount calculated directly on the structural unit of the products created, various technical systems.

In recent years, especially since the 21 st century, rapid development of the human society, scientific and technical innovations and the expansion of the information base, innovations are observed. It should be noted that the Republic of Azerbaijan still has a national innovation system that does not have the necessary level of efficiency indicators and at the same time cannot meet world standards [6, p. 160].

The researches carried out by the economic scientific experts Mishenko V.V. [2], Kuzmin D.V. [5] show that other post-Soviet countries can benefit from the experience of developed countries in the field of innovation activity. At the same time, the formation and development of the innovation system of highly developed countries, especially the United States of America, is of particular interest. It should be taken into account that the United States of America is the most economically developed country in the world [5, p. 67].

Innovation activity is the creation of new and more sophisticated products and services in line with the growing demand of the existing market system. This is the result of scientific research. As a consequence of the implementation of complex scientific, technological, organizational, financial and commercial activities, the innovative activities are provided. According to the recommendation of the European statistics, the classification of innovation activity is grouped as follows [3, p. 250]: research and studies; acquisition of materialized technologies, machinery and equipment (including integrated software), other basic funds necessary for the application of innovation for technological purposes; acquisition of non-materialized technologies (patent rights, permission for the use of inventions, industrial samples and useful models) without patent permissions, knowhow, new technologies in an unstructured form, as well as trademarks, other services with technological composition (injiniring and consultant) in the form of patents; acquisition of innovative software resources; production projects, new products (services) and implementation of new processes; technological development of production and modern design; strong training and retraining of personnel performing the process of application of technological innovations; marketing of new products. 
As can be seen from the research carried out, in any scenario of innovative growth in the national economy, certain prerequisites are envisaged. This growth should be based on the diversified structure of the economy, that is, it should form a solid base and develop on its basis in the form of non-perfect sources of socio-economic development [4, p. 361].

Part of the general problem unsolved earlier. It should be noted that, though the issues of innovative development in different economic spheres were touched upon by economists, the issues of innovative development in the country were not widely studied.

The purpose of the article. The main objective of the study is to examine the main directions of ensuring modern innovative economic development in Azerbaijan.

Presentation of the main material. Innovative growth involves deepening diversification on the sectors, providing more and more sectors of the economy with advanced scientific and technical achievements, technological research and organizational management innovations. At the same time, under the influence of the global economic crisis, when the markets of many countries are shrinking objective, and competition among producers, on the contrary, is growing and becoming more acute, the chances of national entrepreneurs to engage in successful export activities are increasing. In this case, we are talking about the markets of both developed and developing countries.

Innovation capability of the quality and quantity of research and development, the ability of cooperation in the country, diversity and attitudes to the issue to transform different ideas into new goods, and the extent of services. Countries that learn more and offer business models with innovative ideas have a higher ability to create better cooperation and economic integration [2, p. 169].

If we look at the position of some post-Soviet countries (among 141 countries) in terms of macroeconomic stability on the Global Competitiveness Report compiled for 2019, we can see that Tajikistan (98), Georgia (84), Kyrgyzstan (74), Kazakhstan (60), Russia (43) are ahead of Azerbaijan (103). Azerbaijan was only ahead of Ukraine (133) among the post-Soviet countries (Figure 1). The analysis shows that macroeconomic stability indicators should also be raised in Azerbaijan. Despite the implementation of reasonable measures to achieve macroeconomic stability in Azerbaijan in recent years, the position of the country in the last international

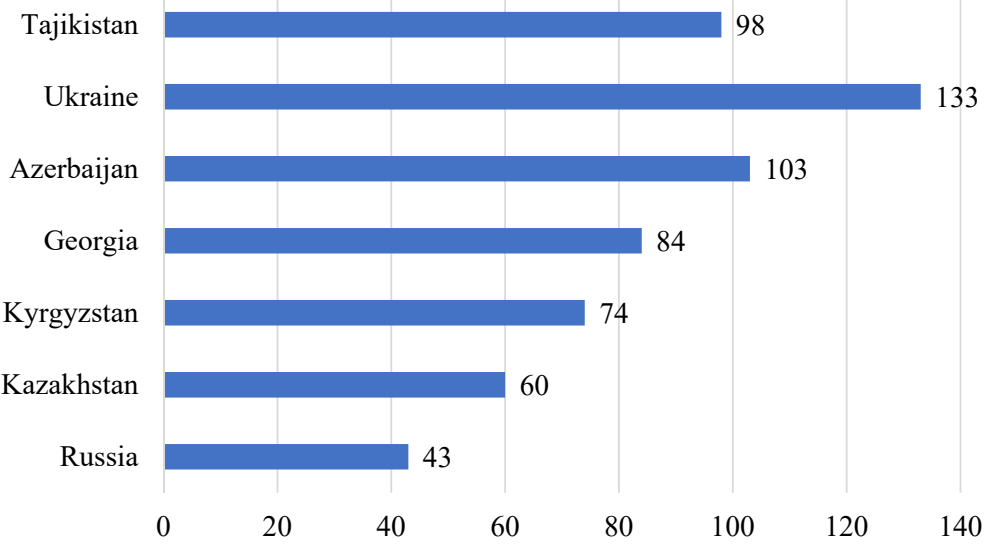

Figure 1. The position of some post-Soviet countries in terms of macroeconomic stability indicators

on the Global Competitiveness Report - 2019 (among 141 countries) [7] rating list has slightly declined in this area. In the Global Competitiveness Report covering recent years, we can see progress in the position of some post-Soviet countries in terms of macroeconomic stability indicators (Figure 1). Therefore, taking into account international experience in our country, it is necessary to implement more modern economic measures in the macroeconomic sphere.

For example, according to the report of the World Economic Forum "Global Competitiveness Index 2019", which characterizes the level of competitiveness of the world countries, the Azerbaijan's economy is ranked 58th among 141 countries (Figure 2). Thus, Azerbaijan has improved its position in the Global Competitiveness Index in comparison with the previous year, and among the post-Soviet countries, as in previous years, it has been ranked in the first place. For example, Georgia, Armenia, Tajikistan, Ukraine, Iran, Armenia were ahead of such countries according to the index. It should be noted that the mentioned international economic organization has a number of important indicators for the determination of this level in the form of objective macroeconomic balance, development of infrastructure areas, quality element and its increasing opportunities, competitiveness, fiscal and monetary policy, educational indicators, measures and opportunities to raise the level of engagement, health, sports and other health opportunities, etc. uses. The indicators mentioned in our country are improving even more as a result of the ongoing economic reforms carried out every year.

In recent years, serious measures have been taken to introduce modern innovations in the national economic spheres in all countries of the world. Thus, despite the fact that some post-Soviet states have different positions on innovation opportunities among 141 countries in the report on international competitiveness for 2019 , these countries are implementing economic measures to move forward in this direction (Figure 3). Thus, despite the fact that Germany is the 1st among all the world countries for innovation opportunities, Russia has been in the best position among the post-Soviet countries in the 32nd place, Ukraine in the 60th place. Azerbaijan's position is the 68th. In this list, Azerbaijan surpasses such countries as Georgia (91st place), Kazakhstan (95th place), Tajikistan (120th place ), Kyrgyzstan (129th place) (Figure 2). The introduction of modern innovative technologies in industrial production processes in Azerbaijan, the increase in the volume of production of products of the economy played an important role in increasing our reputation as an innovative country.

Conclusions. The policy of defining the main promising directions of ensuring modern innovative development in Azerbaijan is of great importance. The developed countries are constantly striving for scientific success in the field of innovation. Entities engaged in modern innovation activities can be considered as subjects of innovation activities.

According to the International Association of Science Parks and Areas of Innovation in recent years, the vast majority of technoparks operating in the world were created with the help of central or local governments. In fact, this process is carried out by creating favorable conditions for the participants of innovative activities in one form or another and providing them with favorable privileges. For example, the active use of ICT and financial subsidies for training are more common in industrial parks around the world. It is considered expedient to apply 


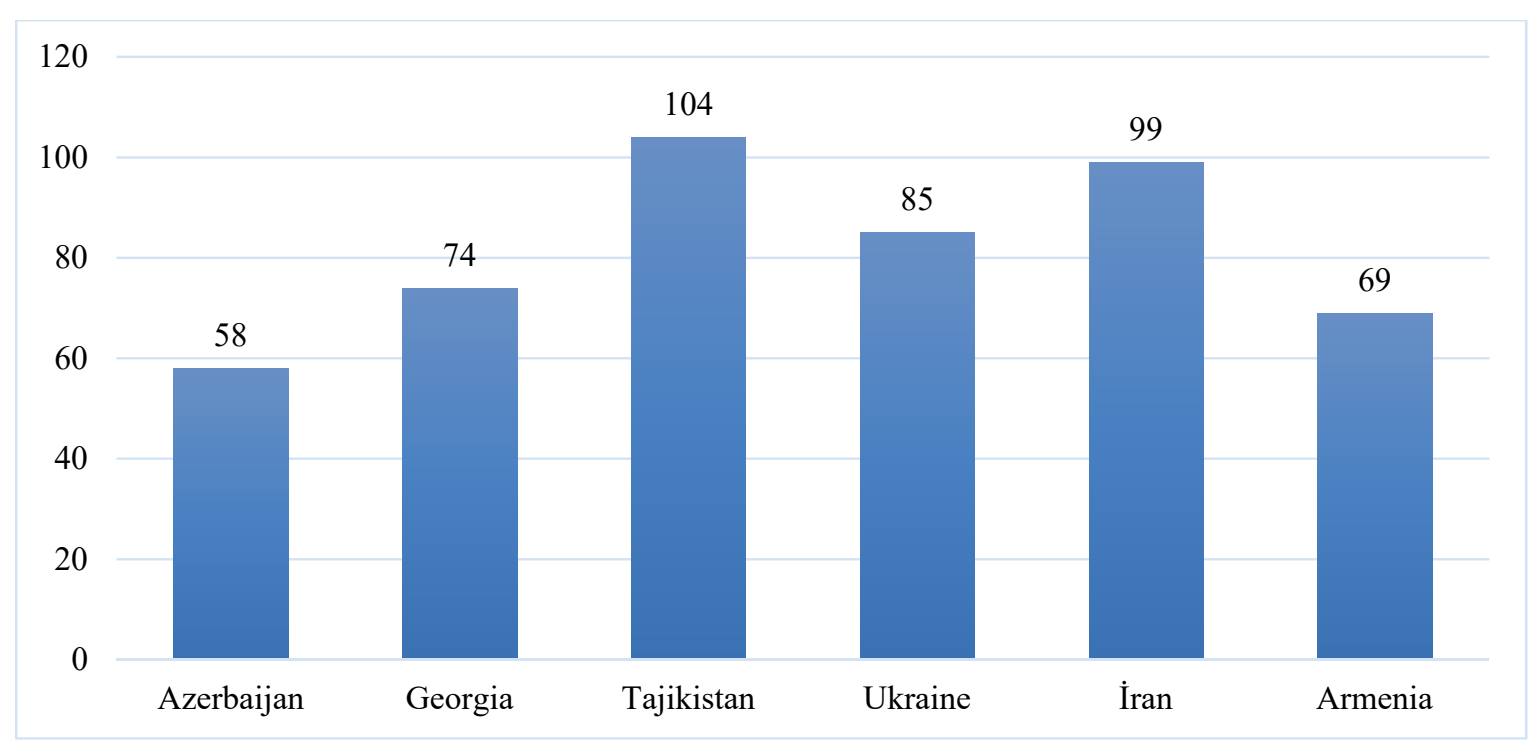

Figure 2. Positions of some post-Soviet countries on the Global Competitiveness Index - 2019 (among 141 countries) [7]

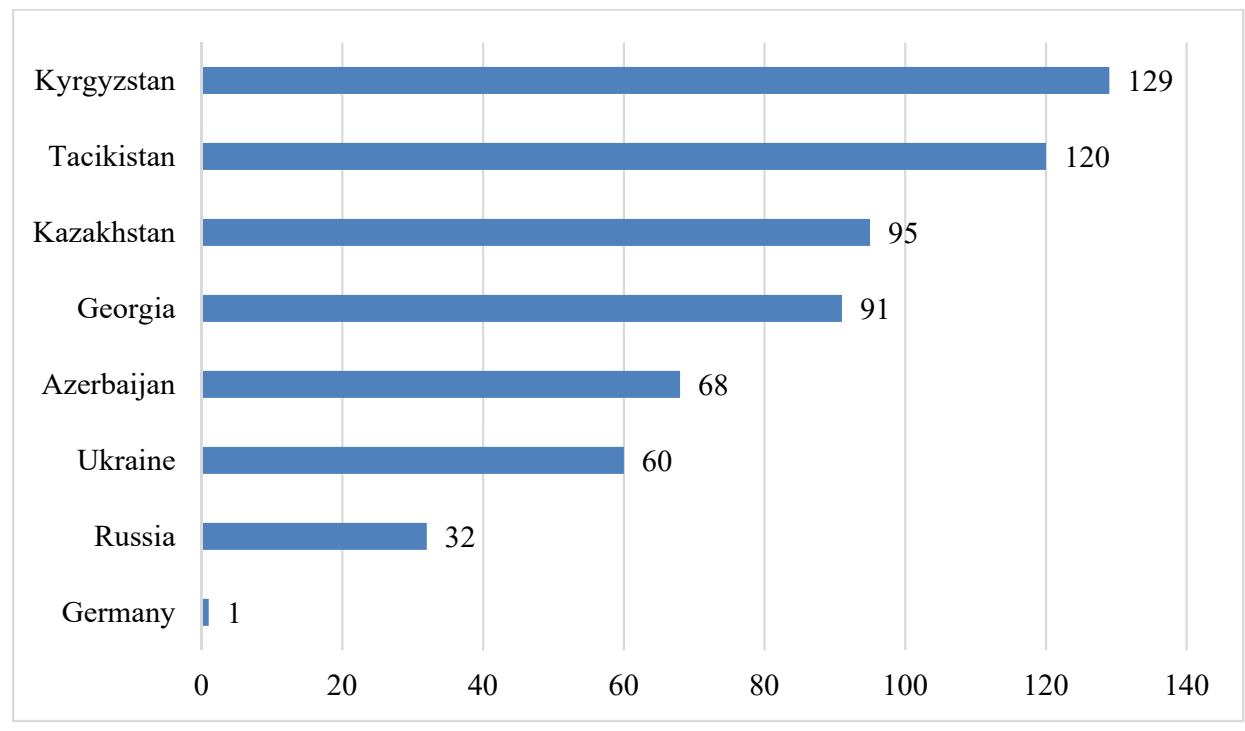

Figure 3. Positions of some countries on innovation opportunities among 141 countries in the Global Competitiveness Report - 2019 [7]

the relevant experience in the Republic of Azerbaijan as well [6, p. 162].

As can be seen from the analysis, the establishment of several industrial parks plays an important role in the organization of modern innovative activities for the development of economic sectors in the Republic of Azerbaijan. In general, taking into account the international experience in Azerbaijan, it is considered expedient to implement the following measures to ensure innovative development: development of modern industrial production areas operating on the basis of innovative and high technologies in the regions; support and financial assistance to small and medium-sized enterprises operating in the field of high innovation and technology in the field of industry, as well as the application of favorable tax incentives; support for access to international markets and export opportunities of modern innovative industrial products; accelerating the process of creating new modern innovative industrial parks jointly with industrial companies of developed countries in the regions; development of new innovation programs, concepts, strategies; to increase the country's attractiveness for local and foreign investment and the level of employment of citizens in industry sector as well.

\section{References:}

1. Shakaraliyev A.Sh. (2011) Ekonomiceskaya politika qosudarstva: torjestva ustoycivoqo i stabilnoqo razvitiya [Economic policy of state: triumph of sustainable and stable development]. Baku: Victory. (in Russian)

2. Mishenko V.V. (2012) Ekonimika regionov [Economy of regions]. Moscow: IK Analitika. (in Russian)

3. Kolesov V.P. and Kulakov, M.B. (2009) Mejdunarodnaya ekonomika [International economics]. Moscow: Infra-M. (in Russian) 
4. Shiray V.I. (2003) Mirovaya ekonomika i mejdubarodnie ekonomiceskie otnosheniya [World economy and international economic relations], Moscow: Dashkov and K. (in Russian)

5. Aliyeva A.A. (2020) Problemi klasterizasiya promishlennosti v Azerbaydjanskoy Respublike. Nasionalnaya konkurentosposobnost, qlobalnaya nestabilnost i makroekonomiceskie ravnovesii, no. 54, pp. 67-74. Baku: Odlar Yurdu. (in Russian)

6. Abdullayev K.N. (2020) Osnovnie osobennosti innovasionnoqo razvitiya nasionalnoy ekonomiki [The main features of the innovative development of the national economy]. Azerbaycanskiy Universitet Arhitekturi i Stroitelstva, pp. 159-162.

7. The Global Competitiveness Report 2019. Available at: www3.werforum.org (дата звернення: 15.11.2020).

\section{Список використаних джерел:}

1. Шакаралиев А.Ш. Экономическая политика государства: торжество устойчивого и стабильного развития. Баку : Victory. 2011. 542 c.

2. Мищенко В.В. Экономика регионов. Москва : ИК Аналитика, 2012. 290 с.

3. Колесов В.П., Кулаков М.В. Международная экономика. Москва : Инфра-М, 2009. 345 с.

4. Ширай В.И. Мировая экономика и международные экономические отношения. Москва : Издательский дом Дашков и К., 2003. $528 \mathrm{c}$

5. Алиева А.А. Проблемы кластеризация промышленности в Азербайджанской Республике. Научные и педагогические известия Университета «Одлар Юрду» Баку : «Одлар Юрду», 2020. № 54. С. 67-74.

6. Абдуллаев К.Н. Основные особенности инновационного развития национальной экономики. Экономика и менеджмент строительства (научно-практический журнал), Азербайджанский Университет Архитектуры и Строительства. Баку : Наука, 2020, С. 159-162.

7. The Global Competitiveness Report 2019. URL: www3.werforum.org (accessed 15 November 2020).

\section{ОСНОВНЫЕ ПЕРСПЕКТИВНЫЕ НАПРАВЛЕНИЯ СОВРЕМЕННОГО ИННОВАЦИОННОГО ЭКОНОМИЧЕСКОГО РАЗВИТИЯ В АЗЕРБАЙДЖАНСКОЙ РЕСПУБЛИКЕ}

Аннотация. Основная цель исследования изучить текущее состояние организации инновационной деятельности в национальной экономике в условиях рыночной отношений. В последние годы в Азербайджане наблюдается рост темпов экономического развития национальной экономики. В международных рейтинговых отчетах Азербайджан ежегодно повышает свою экономическую позицию. В статье также проанализирована позиция Азербайджана в области инноваций в международных рейтинговых отчетах по сравнению с другими странами. Проведенное исследование показывает, что в Азербайджане в последние годы объем инновационной продукции, произведенной в экономической сфере, затраты на технологические инновации невысоки. В то же время в отчете о международной конкурентоспособности инновационные возможности Азербайджана ниже, чем в других странах. В статье проанализированы существующие проблемы в сфере применения современных инноваций в экономической сфере, представлены предложения и рекомендации по их устранению.

Ключевые слова: инновация, экономическая интеграция, национальная экономика, макроэкономика, государственная политика, интеграция, инвестиции.

\section{ОСНОВНІ ПЕРСПЕКТИВНІ НАПРЯМКИ СУЧАСНОГО ІННОВАЦІЙНОГО ЕКОНОМІЧНОГО РОЗВИТКУ В АЗЕРБАЙДЖАНСЬКІЙ РЕСПУБЛІЦІ}

Анотація. Основна мета дослідження - вивчити поточний стан організації інноваційної діяльності в національній економіці в умовах сучасної ринкової економіки. В останні роки в Азербайджані спостерігаються темпи економічного зростання в розвитку національної економіки. У міжнародних рейтингових звітах Азербайджан щорічно підвищує свою економічну позицію. На всі ці процеси позитивно впливає правильна економічна політика, перехід до сучасного інноваційного розвитку. Триваючі реформи, що проводяться на основі міжнародного досвіду в економічній сфері, вважаються дуже ефективними і тривають і в Азербайджані. Крім того, до інноваційних суб'єктів (інвесторів), що фінансують розробку і впровадження інновацій, відносяться банки, Інвестиційні компанії, пенсійні фонди, спеціалізовані компанії. Практика інвестування в інноваційні проекти окремих осіб не так широко поширена в Азербайджані, як в інших регіональних державах. Великі компанії, що здійснюють інвестиції в сучасні інновації, передають початковий етап комерціалізації наукових ідей малим інноваційним підприємствам і захищають свою діяльність від можливих ризиків . Політика визначення основних перспективних напрямків забезпечення сучасного інноваційного розвитку в Азербайджані має важливу актуальність. Саме розвинені країни постійно намагаються домогтися наукових успіхів в області інновацій. Суб'єктами інноваційної діяльності можна вважати суб'єкти, які здійснюють сучасну інноваційну діяльність або залучені в цю діяльність. У статті також проаналізовано позицію Азербайджану в галузі інновацій у міжнародних рейтингових звітах порівняно з іншими країнами. Проведене дослідження показує, що в Азербайджані в останні роки обсяг інноваційної продукції, виробленої в сфері економіки, витрати на технологічні та продуктові інновації невисокі, а в звіті про міжнародну конкурентоспроможність інноваційні можливості Азербайджану нижче, ніж в інших країнах. У статті проаналізовано існуючі проблеми у сфері застосування сучасних інновацій в економічній сфері, подано пропозиції та рекомендації щодо їх усунення.

Ключові слова: інновація економічна інтеграція, національна економіка, макроекономіка, державна політика, інтеграція, інвестиції. 